\title{
Warnings raised over black-market vaccines
}

London. Unicef, the United Nations Children's Fund, is investigating the large-scale theft and black market resale in Burma of expired and potentially toxic vaccines originally intended for Burma's child immunization programmes.

John Gilmartin, head of purchasing for the agency's immunization programme, who is based in Copenhagen, describes as being "of serious concern" reports sent to him by Unicef's Swiss vaccine suppliers of the existence of more than 10,000 doses of unrefrigerated vaccines on sale in an open market in the Burmese capital, Rangoon.

The vaccines are understood to have disappeared from a Unicef warehouse in Burma and to have reappeared later in Rangoon's Mingala Market. The market is a source of cheap drugs and pharmaceutical products, regularly used by local doctors and patients unable to buy drugs at cost price, but often past their expiry date.

Gilmartin has demanded an explanation from Unicef's local representative, Tiruneh Sinnshaw, who has written to the Burmese Department of Health asking them to intervene, to take the vaccines off the market and to "remedy this dangerous situation".

But Stanley Cryz, technical director of the vaccine suppliers, Swiss Serum and Vaccine Institute, who alerted Unicef to the situation, claims that the agency is not acting fast enough. "This is a very serious situation," he says. "Children's lives are at risk, but Unicef seem to be blasé about the whole thing; our representative went to check just a few weeks ago, and the vaccines are still on sale."

The news of the black-market vaccines has shocked researchers. Barry Bloom, of the Howard Hughes Memorial Institute Research Laboratories in New York, said the whole situation is a catastrophe. "Somebody should go to jail for this," says Bloom. "There is a clear lapse in the system somewhere; it needs to be plugged."

Local physicians estimate that between 50 and 60 per cent of Unicef's vaccines end up on the black market. "As a major supplier of vaccines to Unicef, we became concerned with reports surfacing from several SouthEast Asian countries that vaccine lots manufactured at our institute solely for the agency were being resold to the public through black markets," says Cryz.

A representative of the institute noticed

\section{NIH drops reasonable pricing clause}

Washington. Harold Varmus, the director of the National Institutes of Health (NIH), last week made the widely-anticipated announcement that NIH is planning to drop the unpopular 'reasonable pricing' clause from its cooperative research agreements with industry.

The clause was inserted into the agreements that cover cooperative projects between industry and intramural scientists in 1989 following outrage in Congress and elsewhere at the price being charged for the AIDS drug AZT, even though this had been partly developed with federal funds.

That clause effectively gave the government a right to decide the price of drugs developed in any cooperative project with industry, irrespective of how great or small industry's contribution was to the research.

But many companies have since refused to enter cooperative research with intramural researchers, arguing that the existence of the reasonable pricing clause, and the prospect of government involvement in price setting, has discouraged investors.

Over the past year, intramural researchers at NIH have added their voice to the industrial chorus calling for removal of the clause, on the grounds that it has become an impediment to arranging private sector support for their work.

In an attempt to resolve the conflicts that have arisen, Varmus has held two public meetings on the reasonable pricing clause, as well as extensive discussions with the Department of Health and Human Services.

The NIH has now concluded that the cooperative research agreements, despite constituting a small fraction of NIH's intramural activities, are still an important way of advancing biomedical research by encouraging exchange of experimental compounds. To remove the barrier to forming such agreements, NIH is dropping the clause.

Not all groups wanted to see the clause dropped. David Barr, director of treatment, education and advocacy of the Gay Men's Health Crisis in New York, described industry's reluctance to enter research agreements because of the reasonable pricing clause as "slightly hysterical", given the lack of any example of such a clause being abused. "It is all based on how it might be used, and not how it actually was used."

In a statement, the NIH says it acknowledges the existence of such concern. But it points out that AZT, the drug that instigated the clause, was not developed under a formal cooperative research and development agreement (CRADA).

Varmus himself says that the price at which a drug is marketed should not be the responsibility of the NIH, even if its scientists have contributed to its discovery and development. "The NIH's primary programmatic mission, legislative mandate and expertise is in biomedical research, not in product pricing," he says. Helen Gavaghan

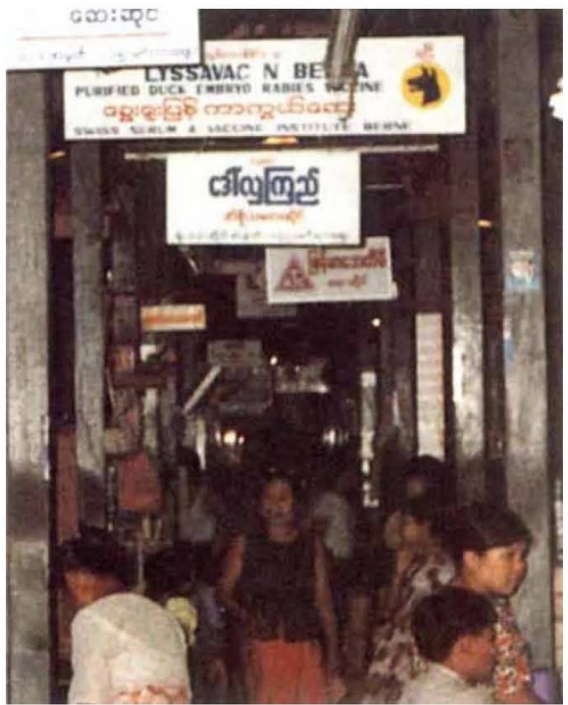

Caveat emptor : vaccines on sale in Burma.

during a visit to Burma a painted sign-board inside the Mingala Market advertising the sale of 'Purified duck embryo rabies vaccine', manufactured by the 'Swiss Serum and Vaccine Institute, Berne' (see illustration). He bought two entire lots and despatched them to Switzerland for testing.

According to Cryz, shipping records confirmed that both lots of vaccines - one for tetanus and the other for diphtheria - had been delivered to Burma up to three years ago as part of a Unicef contract. Furthermore, he claims that, at the time of purchase by the institute's representative, the vaccine was three months past the printed expiry date - with potentially lethal consequences for anyone to whom it was administered.

Investigation by in the institute's laboratories in Switzerland revealed that the vaccine samples had lost their original colour and texture. Cryz says that despite vigorous shaking, the vaccines were extremely difficult to draw into a syringe, while the tetanus vaccine, which had been stored in unrefrigerated conditions, had lost potency and was toxic when injected in laboratory animals.

"This is very depressing," Cryz says. He points out that not only are Unicef vaccines apparently being diverted for economic gain, but many children "undoubtedly remain vulnerable to life-threatening diseases due to this practice".

Cryz adds that unless Unicef clamps down on the black-market diversion of vaccine supplies, manufacturers such as the Swiss Serum and Vaccine Institute will be reluctant to provide vaccines at cost price "while others profit at the expense of those who need safe and effective vaccines". $\mathrm{He}$ suspects the practice is not limited to Burma, and is attempting to confirm reports of similar activities involving two other South-East Asian countries, thought to be Cambodia and Laos.

Ehsan Masood 